РОЗВИТОК ІНФОРМАЦІЙНО-ЦИФРОВОЇ КОМПЕТЕНТНОСТІ

МАЙБУТНІХ ФАХІВЦІВ КОМП'ЮТЕРНИХ ТЕХНОЛОГІЙ

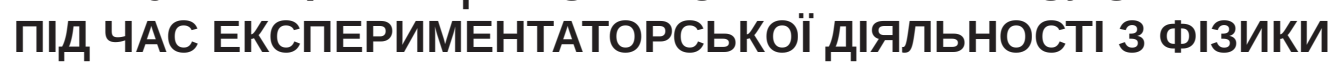
ТА ТЕХНІЧНИХ ДИСЦИПЛІН

\title{
DEVELOPMENT OF INFORMATION AND DIGITAL COMPETENCE OF FUTURE SPECIALISTS OF COMPUTER TECHNOLOGIES DURING EXPERIMENTS ON PHYSICS AND TECHNICAL DISCIPLINES
}

Стаття присвячена одній з актуальних проблем дослідження послідовності розвитку інфрормаційно-цифрової компетентності майбутніх орахівців комп'ютерних технологій під час експериментаторської діяльності з фрізики та технічних дисциплін. Зокрема, акцентовано увагу на особливостях навчального фрізичного експерименту в епоху масової цифрровізації суспільства. Окрема увага приділена компонентам цифрової компетентності згідно з Dig Comp та основними показниками, що характеризують техніку XXI століття. До них належать продуктивність, надійність, довговічність, економічність, екологічність, ергономіка, зовнішня естетика технічних пристроїв. Натепер удосконалення в багатьох галузях йде виключно за цими напрямами. На основі аналізу поняття комп'ютерних технологій, призначення комп'ютера у навчально-дослідній роботі ми визначили роль комп'ютерної техніки та дослідили особливості розвитку інфрормаційно-цисррової компетентності студентів під час виконання навчального фрізичного експерименту. Ми визначили послідовність розвитку інформаційно-цифрової компетентності майбутніх фрахівців комп'ютерних технологій під час експериментаторської діяльності з фрізики та технічних дисциплін. При цьому акцентовано увагу на кожному етапі виконання експерименту та тому компоненті інформаційно-цифррової компетентності (загальному чи професійному), що розвивається на такому етапі. Отже, на нашу думку, одним із завдань викладача срізики та технічних дисциплін $є$ його психолого-педагогічна готовність донести інфрормацію про таку взаємодію в електронному вигляді до свідомості студентів. Для успішної реалізації цього завдання необхідно забезпечити планування й організацію навчання та професійну підготовку фрахівця для експериментаторської роботи та забезпечити розвиток у нього певного рівня інфрормаційно-цифрової компетентності.

Ключові слова: фахівці комп'ютерних технологій, інформаційно-цифрова компетентність, розвиток, навчальний фрізичний експе- римент, експериментаторська діяльність, навчання фрізики і технічних дисциплін.

The article is devoted to the actual problem. This is a study of the sequence of development of the information and digital competence of future computer technology specialists during experiments on physics and technical disciplines. In particular, attention was paid to the peculiarities of the educational physical experiment in the era of mass digitalization of society. Particular attention is paid to Dig Comp. We reviewed the main indicators characterizing the technology of the XXI century. These include performance, reliability, durability, cost effectiveness, environmental friendliness, ergonomics, external aesthetics of technical devices. At present, improvements in many areas are solely in these areas. On the basis of the analysis of the concept of computer technology, the appointment of a computer in teaching and research we determined the role of computer technology and investigated the peculiarities of the development of information and digital competence of students during the implementation of a physical experiment. We have identified the sequence of development of the information and digital competence of future computer technology specialists during experiments in physics and technical disciplines. At the same time, attention is focused on each stage of the experiment. We reviewed each component of information and digital competence (general or professional) that are developing at this stage. So, we have identified one of the tasks of the teacher of physics and technical disciplines. This is his psychological and pedagogical readiness to convey information about such interaction electronically to the consciousness of students. To succeed in this task it is necessary to ensure the planning and organization of training and professional training of a specialist for experimental work. It is also necessary to ensure that he develops a certain level of information and digital competence.

Key words: computer technology specialists, information and digital competence, development, physical experiment, experimental activity, physics training and technical disciplines.
Постановка проблеми у загальному вигляді. Особливість сучасної науки полягає у тому, що вже більше трьохсот років постійно збільшується наукова інформація виокремленої 3 натурфілософії фрізики. За результатами роботи провідних центрів поповнюються як теоретичні основи науки фрізики, так і її практичне впровадження у виробництво, техніку та технології, що знаходить своє відображення в освітньому процесі технічних дисциплін.
Проведені нами дослідження [9; 10] стану розвитку сучасної науки та рівня запровадження новітніх знань у зміст посібників з фрізики та технічних дисциплін (ФТД) педагогічних закладів вищої освіти (ЗВО) показали його відставання на 30-40 років.

Рефрормування освіти має відповідати потребам розвитку техногенно-інформаційного та цифрового суспільства. Використання цифрових технологій в освіті має носити багатоплатформний 
наскрізний характер, тобто використовуватися не лише на заняттях інформатики в окремій аудиторії, як зазвичай, а під час навчання інших предметів, взаємодії суб'єктів навчання один з одним та 3 викладачами, реальними експертами, здійснення досліджень, індивідуального навчання.

Фізика є прикладною експериментальною наукою. В освітньому процесі з технічних дисциплін експеримент також відіграє велике значення. При цьому $є$ відставання розробки та впровадження В освітній процес нового покоління приладів, обладнання, наочності. Своєю чергою такий підхід потребує розвитку наявних та пошуку нових методичних підходів до їх запровадження.

Аналіз останніх досліджень і публікацій. Становлення навчального фрізичного експерименту (НФЕ) в Україні пов'язане з іменами П.С. Атаманчука, А.К. Бабенка, О.І. Бугайова, В.П. Вовкотруба, Є.В. Коршака, А.М. Кух, В.В. Мендерецького, Б.Ю. Миргородського, М.І. Садового, В.П. Сергієнка, С.П. Слєсаревського, В.В. Слюсаренко, Р.К. Шабаля, М.С. Шульги, В.А. Франковського $[1 ; 3 ; 4 ; 5 ; 6 ; 7 ; 8 ; 11]$ та ін.

Виділення не вирішених раніше частин загальної проблеми. На нинішньому етапі розвитку виробничих технологій змінюється експериментальна база курсу ФТД, на зміну старому приходить нове покоління приладів, використання яких вимагає зовсім іншого рівня сорормованості компетентностей, зокрема інформаційно-цифрової (ІЦК).

При цьому експериментаторська діяльність відіграє одну з провідних ролей у разі розвитку ІЦК у майбутніх фрахівців комп'ютерних технологій (КТ).

У науці нині виникла реальна можливість переосмислити епоху створення та використання нового інфрормаційно-цифрового (ІЦ) навчального обладнання.
Мета статті - дослідити послідовність розвитку ІЦК майбутніх фрахівців КТ під час експериментаторської діяльності з фрізики та технічних дисциплін.

Виклад основного матеріалу дослідження. Узагальнюючи досвід роботи фрахівців різних галузей, Європейською комісією створено Рамку цифрової компетентності для громадян (Dig Comp 2.0: Digital Competence Framework for Citizens), до якої увійшли описи дескрипторів та рівнів володіння цифровою компетентністю [14]. Dig Comp 2.0 визначає основні компоненти цифрової компетенції у 5 галузях (табл. 1). Рамка Dig Comp [13] була схвалена представниками держав-членів ЄС у тематичній робочій групі «Програма освіти та навчання 2020 «ІКТ та освіта». Деякі держави-члени вже використовують Dig Comp різними способами, а також мають різні європейські реалізації (https://ec.europa.eu/jrc/en/digcomp/ implementation).

У таблиці 1 здійснено аналіз основних компонент цифрової компетентності згідно з Dig Comp 2.0. Окреслено 5 компонент цифрової компетентності та розкрито характеристики і зміст окремо кожної компоненти цифрової компетентності.

Виходячи 3 того, що XXI століття характеризується стрімкою цифровізацією всіх ссрер життя суспільства, техніка зазнає докорінних змін. До основних показників, що характеризують техніку, ми віднесли:

- продуктивність - кількість продукції (інфрормації тощо), що виготовляється, обробляється, перевозиться за одиницю часу;

- надійність - здатність технічного пристрою без відмов виконувати свої фрункції на належному рівні якості або відповідати поставленим вимогам протягом заданого проміжку часу;

- довговічність - у це поняття входить не тільки фрізичний знос, останніми роками різко позна-

Таблиця 1

Основні компоненти цифрової компетентності згідно з Dig Comp 2.0

\begin{tabular}{|c|c|c|}
\hline № & Компоненти & Характеристика і зміст компонент цифрової компетентності \\
\hline 1 & $\begin{array}{c}\text { інфоормація } \\
\text { та циоррові дані }\end{array}$ & $\begin{array}{l}\text { орормулювати інформаційні потреби, знаходити та отримувати цифрові дані, } \\
\text { інорормацію та вміст; судити про відповідність джерела та його зміст; зберігати, } \\
\text { керувати та організувати цифрові дані, інформацію та контент }\end{array}$ \\
\hline 2 & $\begin{array}{l}\text { комунікація } \\
\text { та співпраця }\end{array}$ & $\begin{array}{l}\text { взаємодіяти, спілкуватися та співпрацювати за допомогою цифрових технологій, } \\
\text { одночасно усвідомлюючи різноманітність культур та поколінь; брати участь у } \\
\text { житті суспільства через публічні та приватні цифрові служби та громадянське } \\
\text { співтовариство; для управління цифровою ідентифікацією та репутацією }\end{array}$ \\
\hline 3 & $\begin{array}{c}\text { створення } \\
\text { цифррового контенту }\end{array}$ & $\begin{array}{l}\text { створення та редагування цифрового контенту; для вдосконалення та інтеграції } \\
\text { інформації та контенту в наявний набір знань під час розуміння того, як слід } \\
\text { застосовувати авторські права та ліцензії; знати, як дати зрозумілі інструкції для } \\
\text { комп'ютерної системи }\end{array}$ \\
\hline 4 & безпека & $\begin{array}{l}\text { захист пристроїв, вмісту, особистих даних та конфіденційності в цифрових } \\
\text { середовищах; захистити фрізичне та психологічне здоров'я, а також бути в курсі } \\
\text { цифрових технологій для соціального добробуту та соціальної інтеграції; звернути } \\
\text { увагу на вплив цифрових технологій на навколишнє середовище та їх використання }\end{array}$ \\
\hline 5 & вирішення проблем & $\begin{array}{l}\text { визначити потреби та проблеми, а також вирішити концептуальні проблеми та } \\
\text { проблемні ситуації в цифрових середовищах; використовувати цифрові інструменти } \\
\text { для реалізації інноваційних процесів; бути в курсі цифрової еволюції }\end{array}$ \\
\hline
\end{tabular}


чилася проблема так званого морального зносу техніки, тобто коли експлуатація цілком справних пристроїв стає економічно невигідною або недоцільною через появу досконаліших рішень;

- економічність - кількість матеріальних ресурсів, часу, енергії, що витрачаються на виробництво одиниці продукції, переміщення одиниці вантажу тощо.

Основа технічного прогресу - підвищення основних показників усіх видів техніки. Такий процес називається модернізацією.

Останніми роками також багато уваги стало приділятися таким раніше другорядним показникам, як екологічність, ергономіка, зовнішня естетика технічних пристроїв. Натепер удосконалення в багатьох галузях йде виключно за цими напрямами. Якщо поліпшення зручності використання і зовнішнього вигляду пристроїв відбувається відповідно до запитів кінцевих споживачів, то екологічні параметри в основному регулюються законодавчо. Все це визначає вимоги до рівня підготовки фахівців з вищою освітою, зокрема в галузі КТ. Досліджуючи освітній процес з ФТД, не можна оминути увагою проблему розвитку в них під час експериментаторської діяльності.

У сучасних експериментальних дослідженнях спостерігається використання досить широкого спектра ІЦ ресурсів, які використовуються в освітньому процесі з ФТД.

На основі аналізу поняття КТ, призначення комп'ютера у навчально-дослідній роботі ми визначили роль комп'ютерної техніки та дослідили особливості розвитку ІЦК студентів під час виконання НФЕ.

Зокрема, комп'ютерні презентації Microsoft Power Point можна застосовувати на різних видах і етапах заняття. Вони ефективні [2] під час проведення лекцій, практичних занять, лабораторних робіт. Також студентам часто пропонується як самостійне індивідуальне науково-дослідне завдання готувати презентації до відповідних занять, що є частиною їхньої дослідницько-пошукової діяльності.

Ефективними $€$ програми підтримки проведення лабораторних робіт в умовах імітації [2] комп'ютерною програмою реального досліду. Програми такого типу, що зазвичай є віртуальними лабораторіями, знаходять застосування в галузі природничих дисциплін, наприклад, «Віртуальна фрізична лабораторія», «Віртуальна хімічна лабораторія» (АТЗТ «Квазар-Мікро Техно», 2007), що містять можливості тривимірного бачення, маніпулювання об'єктами, дослідження закономірностей їхньої поведінки.

Доступними для викладача $€$ розроблені графрічні пакети та оболонки (Corel, 3D-Studio, Macromedia Flash, Micro-Cap та інші), що дають змогу вирішувати конкретні практичні завдання акме за допомогою IKT без знання мов програмування високого рівня. На нашу думку [2], найбільш прийнятними для використання в школі $€$ оболонки PowerPoint i Corel Move. До таких дій мають бути готові майбутні педагоги.

Традиційно експериментальне вивчення явищ, понять, закономірностей природи проводиться в штучній чи природній лабораторії [12].

Ми розглядаємо штучну лабораторію як середовище, де монтується установка 3 наявного обладнання, приладів за заздалегідь підготовленими схемами, кресленнями, за допомогою яких досягається певне наближення, ефект природного явища та демонструються ті чи інші властивості досліджуваного об'єкта [12]. Практичне пізнання в цьому разі наштовхується на значні ускладнення. В земних умовах відсутня можливість ізолювати предмет дослідження в «чистому вигляді». Будьяка штучна ізоляція спотворює природну картину. Тому абсолютна більшість дослідів, спостережень проводиться 3 певною точністю, з проявом побічних ефректів, які нерідко вимагають значних ускладнень не лише обладнання, а і теоретичних обґрунтувань.

У природній лабораторії експеримент проводиться виходячи з умов самої природи. До таких дослідів можна віднести дифракцію на дрібних частинках від Місяця, розсіювання світла, сонячні затемнення, розкладання світла в спектр, оптичні есректи тощо. Це майже «чисті» досліди. Роль суб'єктів навчання в таких лабораторіях різна. Здебільшого вони стають складовою частиною таких дослідів. Тому дослідити їх доцільно через вивчення експериментальної діяльності викладача та студента. 3 дидактичної точки зору така діяльність може проводитись на репродуктивному, проблемному, пошуковому чи дослідницькому рівнях. Наприклад, залежно від способу теоретичного відношення до Всесвіту встановлюється сорера знань, рівень активізації розумової діяльності учасників процесу навчання. На противагу сорері предметно чуттєвого пізнання природи розгортається відповідна фрорма експериментаторської діяльності. Відсутність такої взаємодії також $€$ рівнем розв'язання проблеми експерименту.

Експеримент у технічних науках і на виробництві має певні особливості: дослідник самостійно організовує умови його проведення з урахуванням виходу на практичне застосування у виробничих процесах; експериментатор може прогнозувати зміну варіантів умов та кінцевий результат прояву досліджуваного технічного застосування (технологічного процесу); в експерименті можливі кількісні та якісні зміни 3 метою виокремлення окремих деталей процесу чи заміни деталей, вузлів, блоків установки; із запровадженням КТ зростає роль моделювання теорії у разі підготовки та проведення експери- 
менту; нового підходу набуває точність технічних засобів експерименту, що складаються 3 багатофрунціональної електронної апаратури, прецизійних механічних пристроїв, високочутливих приладів; експеримент набуває властивостей глобалізації. Для реалізації всього цього в освітньому процесі від суб'єктів навчання необхідний відповідний рівень розвитку ІЦК. Для розв'язання зазначених проблем та на основі аналізу основних компонент циоррової компетентності (табл. 1) нами запропонована послідовність розвитку інформаційно-цифрової ком- петентності майбутніх фрахівців комп'ютерних технологій під час експериментаторської діяльності з фрізики та технічних дисциплін (рис. 1).

Висновки. Отже, на нашу думку, одним із завдань викладача ФТД $є$ його психолого-педагогічна готовність донести інформацію про таку взаємодію в електронному вигляді до свідомості студентів. Для успішної реалізації цього завдання необхідно забезпечити організацію навчання та професійну підготовку фрахівця для експериментаторської роботи та забезпечити розвиток у нього певного рівня ІЦК.
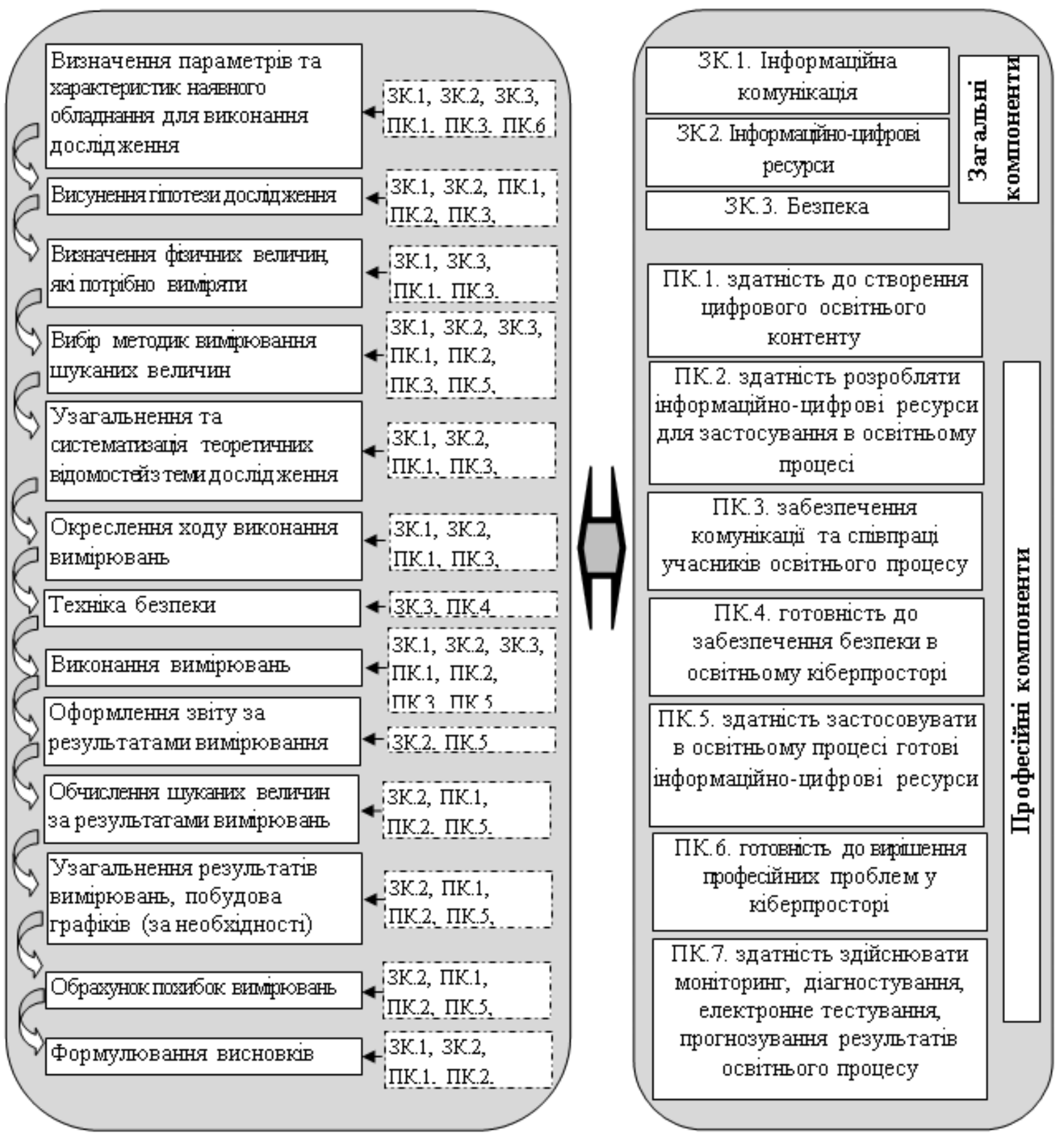

Рис. 1. Послідовність розвитку ІЦК у майбутніх фрахівців КТ під час виконання експериментаторської діяльності 


\section{БІБЛІОГРАФІЧНИЙ СПИСОК:}

1. Атаманчук П.С. Основні пріоритети та орієнтири якісного навчання фрізики. Збірник наукових праць Кам'янець-Подільського національного університету імені Івана Огієнка. 2012. Вип. 18. С. 5-8.

2. Бобик І.В., Садовий М.І., Трифонова О.М. Моделювання як засіб реалізації акмеологічного підходу. Наукові записки. Серія: Педагогічні науки (КДПУ ім. В. Винниченка). Кіровоград, 2015. Вип. 135. С. 56-61.

3. Бугаев А.И. Методика преподавания фризики в средней школе. Теоретические основы : учебное пособие для студентов педагогических институтов по фризико-математической специальности. Москва : Просвещение, 1981. 288 с.

4. Вовкотруб В.П. Ергономічний підхід до розвитку шкільного фрізичного експерименту : монографрія. Київ : Вид-во НПУ імені М.П. Драгоманова, 2002. $280 \mathrm{c}$.

5. Коршак Є.В., Миргородський Б.Ю. Методика і техніка шкільного фрізичного експерименту: Практикум : навчальний посібник для педагогічних інститутів. Київ : Вища школа, 1981. 280 с.

6. Кух А.М., Кух О.М. Технічне забезпечення сучасного освітнього середовища : навчально-методичний посібник. Кам'янець-Подільський : К-ПДУ, інформаційно-видавничий відділ, 2005. 130 с.

7. Мендерецький В.В. Методична система експериментальної підготовки майбутніх учителів фрізики : дис. ... д-ра пед. наук : 13.00.02. НПУ ім. М.П. Драгоманова. Київ, 2007. 488 с.

8. Садовий М.І., Сергієнко В.П., Трифронова О.М., Сліпухіна І.А., Войтович І.С. Методика і техніка експерименту з оптики : посібник для студентів фрізичних спеціальностей вищих педагогічних навчальних закладів та вчителів фрізики. Луцьк : Волиньполіграфр, 2011. 292 c.

9. Садовий М.І., Трифонова О.М. Історія фрізики 3 перших етапів становлення до початку XXI століття : навчальний посібник для студентів фрізико-математичних фракультетів вищих педагогічних навчальних закладів. Вид. 2-ге, переробл. та доп. Кіровоград : ПП «Центр оперативної поліграсфії «Авангард», 2013. 436 с.

10. Садовий М.І., Трифонова О.М. Сучасна фрізична картина світу: навчальний посібник для студентів педагогічних вищих навчальних закладів. Кіровоград : ПП «ЦОП «Авангард», 2016. 180 с.

11. Слюсаренко В.В. Методика фрормування експериментальних компетентностей старшокласників 3 використанням вимірювального комплекту на уроках срізики : дис. ... канд. пед. наук : 13.00.02. КДПУ ім. В. Винниченка. Кіровоград, 2015. 272 с.

12. Трифонова О.М. Формування професійних якостей майбутніх учителів фрізики до застосування сучасних демонстраційних приладів. 3б. наук. пр. Кам'янець-Подільського держ. ун-ту. Серія педагогічна. Вип. 17: Інноваційні технології управління компентнісно-світоглядним становленням учителя: фрізика, технології, астрономія. Кам'янецьПодільський, 2011. С. 126-129.

13. DigComp. URL: https://ec.europa.eu/jrc/en/ digcomp/digital-competence-framework (дата звернення: 07.01.2019).

14. Vuorikari R., Punie Y., Carretero Gomez S., Vanden Brande G. DigComp 2.0: The Digital Competence Framework for Citizens. UpdatePhase 1: The Conceptual Reference Model. Luxembourg Publication Office of the European Union. 2016. EUR 27948 EN. DOI:10.2791/11517/- 44 р. (дата звернення: 07.01.2019). 